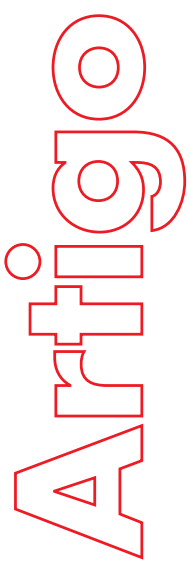

Revista

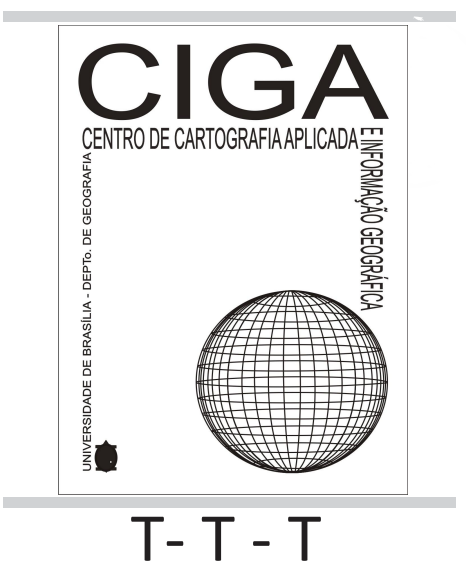

Revista Eletrônica: Tempo - Técnica - Território, V.11, N.2 (2020), 99:121 ISSN: 2177-4366

\section{ANÁLISE DAS ABORDAGENS EM RELACÃO À CULTURA E HISTÓRIA AFRICANA E AFROBRASILEIRA EM LIVROS DIDÁTICOS DO ENSINO MEDIO}

\section{Marcelo Luiz Rodrigues Lucas de Souza}

Como citar este artigo:

Souza, M.L, R. L.

ANÁLISE DAS ABORDAGENS EM RELAÇÃO À CULTURA E HISTÓRIA AFRICANA E AFROBRASILEIRA EM LIVROS DIDÁTICOS DO ENSINO MÉDIO - Revista Eletrônica: Tempo - Técnica - Território, v.11, n.2 (2020),p.99:121 ISSN: 2177-4366.

Disponível em: http://periodicos.unb.br/index.php/ciga/

Este obra está licenciado com uma Licença Creative Commons Atribuição - Não Comercial 4.0 Internacional. 


\section{ANÁLISE DAS ABORDAGENS EM RELAÇÃo À CULTURA E HISTÓRIA AFRICANA E AFROBRASILEIRA EM LIVROS DIDÁTICOS DO ENSINO MÉDIO}

\section{Marcelo Luiz Rodrigues Lucas de Souza}

Graduando em Geografia pela Universidade de Brasília, Disciplina GEOAFRO - $1^{\circ}$ Semestre 2020 E-mail: marcelolucasunb@gmail.com

RESUMO: Quatro livros foram analisados, sendo 3 deles da mesma franquia e então, muitas vezes durante o artigo, eles foram tratados com um só. Os livros didáticos costumam utilizar diversos conceitos geográficos, às vezes de origens distintas, mas que se assemelham em algum ponto, também costumam utilizar diversas correntes geográficas pois os autores acham que a variabilidade complementa o aprendizado. Conforme a análise, foi possível chegar à conclusão que talvez os livros precisem de uma certa uniformização da linhagem de pensamento e de mudança em alguns pontos, principalmente quando se trata de assuntos relacionados à África e à realidade afro-brasileira. A sugestão inicial é seguir o pensamento do geógrafo Raffestin pois julgo que sua forma de pensar território tira o poder da mão das elites brancas e do Estado racista e coloca ele nas mãos de todos.

Palavras-chave: Livro didático; Geografia; Licenciatura; África; Brasil; Afro-Brasileiro.

ABSTRACT: Four books were analyzed, 3 of them from the same franchise so, many times during the article, they were treated like only one. Textbooks tend to use different geographical concepts, sometimes from different origins, but similar at some point, also tend to use different geographical scholarships because the authors think that the variability complements the learning process. According to the analysis, it was possible to conclude that perhaps the books need a certain uniformity of the lineage of thought and change in some points, especially when it comes to issues related to Africa and the Afro-Brazilian reality. The initial suggestion is to follow the thinking of geographer Raffestin because I think that his way of thinking territory takes the power out of the hand of white elites and the racist State and puts it in the hands of everyone.

Keywords: Textbook; Geography; Licentiate; Africa; Brazil; Afro-Brazilian

\section{INTRODUÇÃO}

Durante alguns anos, por meio de lei, afrodescendentes não podiam frequentar escolas, e até hoje, mesmo sem essa lei, negros continuam tendo dificuldade para acessar escolas. Esse distanciamento proposital dos negros ao conhecimento por meio do Estado racista e de brancos escravocratas, e a tentativa de apagamento da história e da cultura negra, fez com que, durante anos, 
negros fossem distanciados dos livros, tanto no sentido de lê-los quanto no sentido de estar presente neles de forma fidedigna. Com racistas podendo pintar e bordar com a imagem e com a história africana e de afrodescendente, alguns livros didáticos ficaram cheios de estereótipos e histórias mal contatas. Após ler alguns livros didáticos, me deparei com uma franquia de livros que achei excelente por tratar de assuntos africanos e afro-brasileiros com detalhes e profissionalidade, e me deparei com um livro que achei medíocre quando se trata desses assuntos. Após uma conversa com professores auxiliares e monitor da matéria Geografia Africana e Afrobrasileira, decidi que não faria a análise somente de uma obra, mas sim uma comparação entre duas obras opostas, para que assim a análise fique mais rica e fique mais explicito a forma correta de abordar os assuntos de interesse desse artigo.

\section{DESENVOLVIMENTO}

\section{FICHA TÉCNICA}

\subsection{GEOGRAFIA: ENSINO MÉDIO}

O primeiro livro didático utilizado para a análise é “GEOGRAFIA - ENSINO MÉDIO” lançado em 2007 e distribuído de forma gratuita nas escolas públicas do Paraná por intermédio da secretaria de Estado da Educação. O livro escolhido está em sua segunda edição, é a versão dos alunos (a única versão que foi possível encontrar atualmente) e os autores são André Aparecido Alflen, Gisele Zambone, João Carlos Ruiz, Leda Maria Correa Moura, Márcia Regina Garcia e Rosélia Maria Soares Loch. O livro contem somente um volume para o ensino médio inteiro, de acordo com o sumário, ele é dividido em 5 (cinco) partes, sendo uma delas a apresentação, e as outras quatro partes os conteúdos propriamente ditos. Os conteúdos são divididos em “Conteúdo Estruturante” e cada um tem uma introdução, essa estrutura é algo semelhante à estruturação por “unidades”, e cada Conteúdo Estruturante/Unidade é dividido em capítulos, que ao final tem referências e alguns tem glossário. 


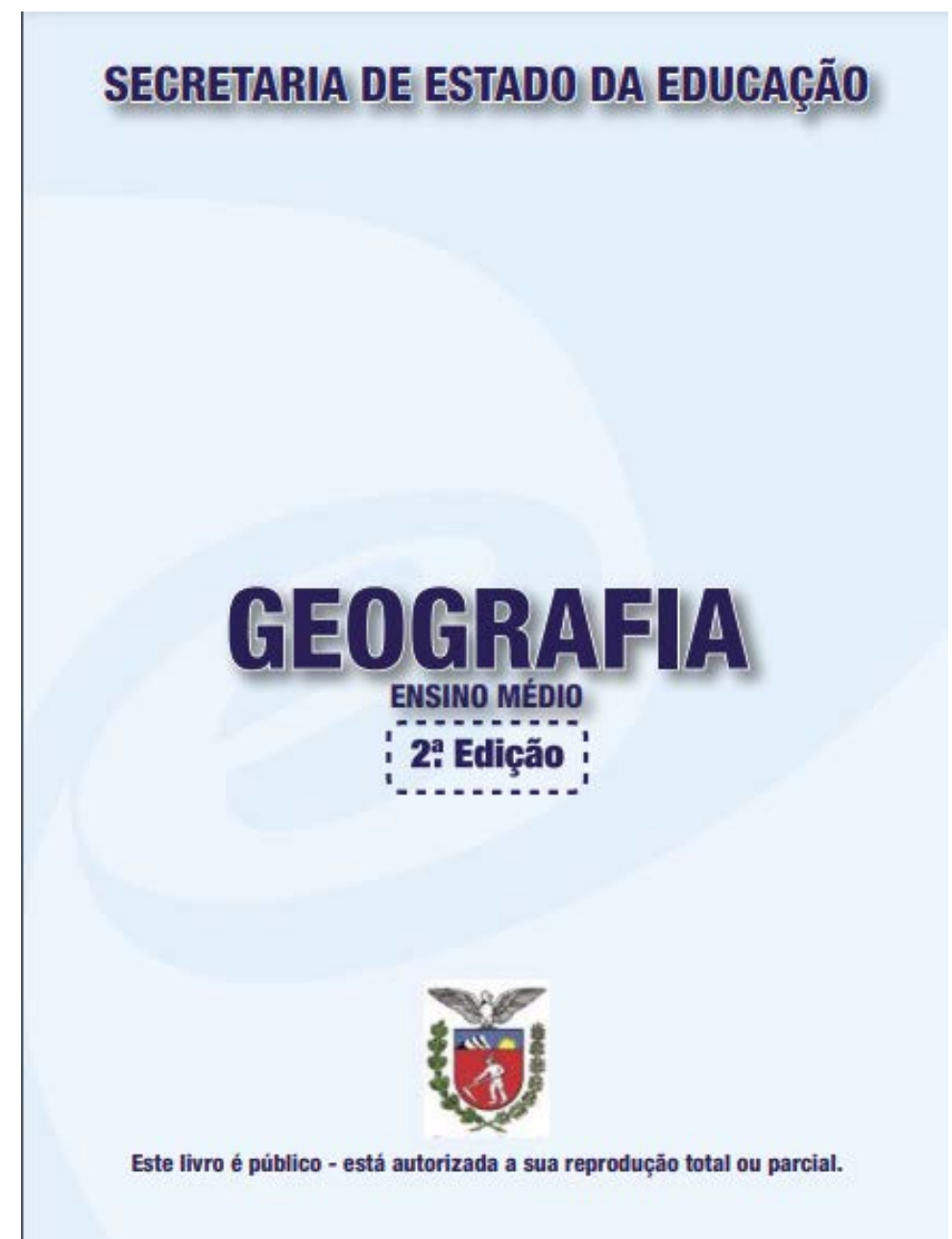

IMAGEM 1: Capa do livro didático GEOGRAFIA: ENSINO MÉDIO (2007). Disponível em: https://5ca0e999-de9a-47e0-9b77-7e3eeab0592c.usrfiles.com/ugd/5ca0e9_23a7e4b5793148199e49119073354160.pdf

\subsection{TERRITÓRIO E SOCIEDADE NO MUNDO GLOBALIZADO: ENSINO MÉDIO}

Os outros três livros fazem parte da mesma coletânea, todos tem o mesmo título, foram lançados em 2016, estão na $3^{\circ}$ Edição e tem os mesmos autores, só pautam áreas diferentes da Geografia, então nesse artigo eles serão tratados como um livro único que foi dividido em partes. O livro analisado tem a versão do aluno e a versão Manual do Professor, sendo a segunda opção a versão utilizada para análise, a coletânea é dividida em três volumes, cada um dedicado a um ano do Ensino Médio. Os três volumes são assinados pelos autores Elian Alabi Lucci, Anselmo Lazaro Branco e Cláudio Mendonça. O livro é dividido em volumes, e cada volume é dividido em unidades, cada unidade é dividida em capítulos, e alguns capítulos chegam a ter itens, e ao final de cada capítulo costuma ter sessões como a sessão Contraponto e a sessão Compreensão e análise, que complementam o ensinamento e estimulam o aprendizado. Segundo o sumário, o Volume 1 tem cinco unidades e 14 capítulos, o Volume 2 tem quatro unidades e 12 capítulos e o Volume 3 tem quatro unidades e 11 capítulos, e o final de cada unidade conta com as sessões: MUNDO: POLÍTICO -2016, RESPOSTAS DE ENEM E VESTIBULARES, ÍNDICE REMISSIVO, BIBLIOGRAFIA E MANUAL DO PROFESSOR - ORIENTAÇÕES DIDÁTICAS. 


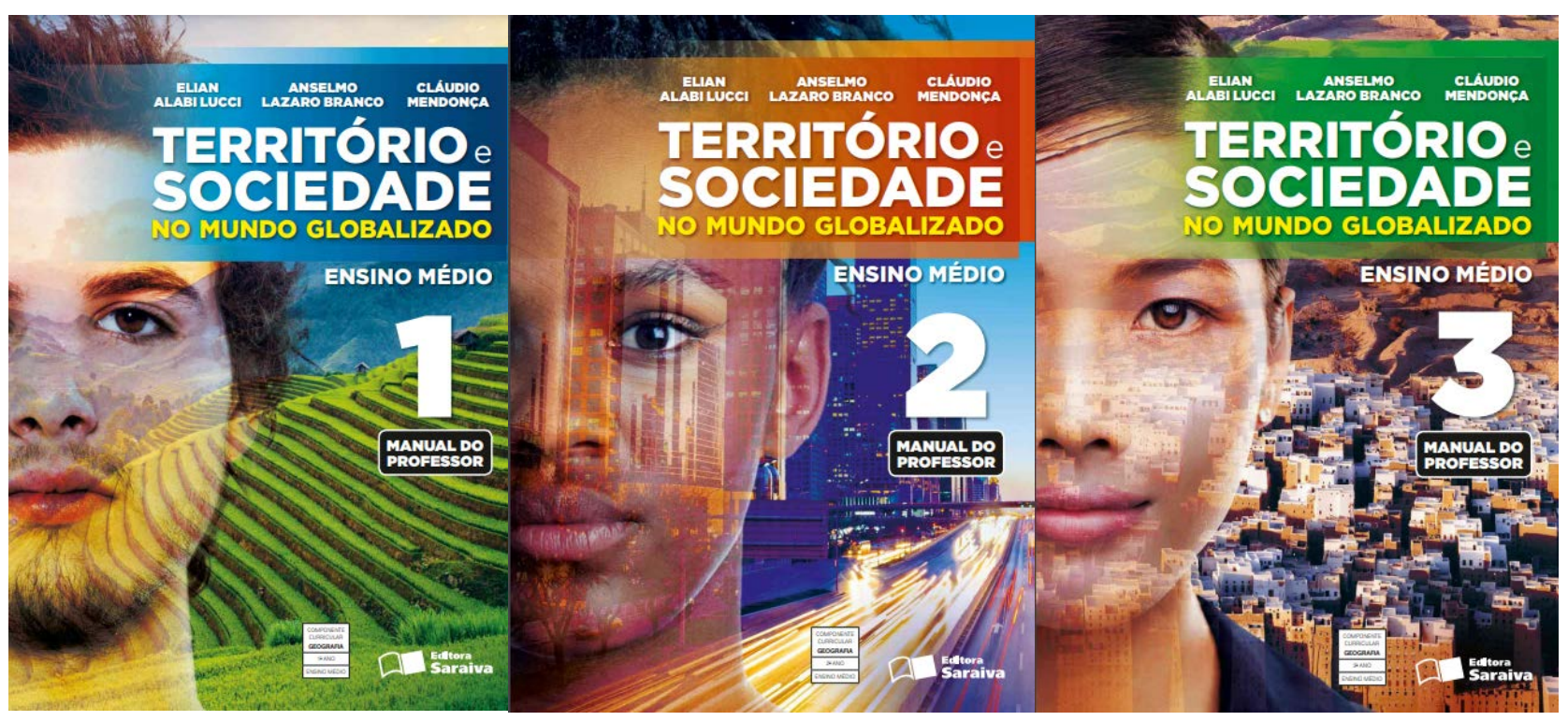

IMAGEM 2: Capa do livro didático TERRITÓRIO E SOCIEDADE NO MUNDO GLOBALIZADO: ENSINO MÉDIO VOLUME 1 (2016). Disponível em:

https://www.amazon.com/clouddrive/share/Yz4bgTOoCD9akAPdUcK42sOi71itT3VkDze7wAhj0Nw?_encoding=UTF $8 \& *$ Version* $=1 \& *$ entries*=0\&mgh $=1$

IMAGEM 3: Capa do livro didático TERRITÓRIO E SOCIEDADE NO MUNDO GLOBALIZADO: ENSINO MÉDIO VOLUME 2 (2016). Disponível em:

https://www.amazon.com/clouddrive/share/t1qCXbH4c1chqPu9vUIuoxBO7TzYKp3dlQYbZnzATdA?_encoding=UTF 8\&\%2AVersion\%2A=1\&\%2Aentries\%2A=0\&mgh=1

IMAGEM 4: Capa do livro didático TERRITÓRIO E SOCIEDADE NO MUNDO GLOBALIZADO: ENSINO MÉDIO VOLUME 3 (2016). Disponível em:

https://www.amazon.com/clouddrive/share/EYc49Scfh88NehqEybRyPeQwYsFQT8SWRIslnRzFRTt?_encoding=UTF 8\&\%2AVersion\%2A=1\&\%2Aentries\%2A=0\&mgh=1

\section{CONCEITOS GEOGRÁFICOS ADOTADOS NO LIVRO}

\subsection{GEOGRAFIA: ENSINO MÉDIO}

A introdução do primeiro Conteúdo Estruturante deixa explicito que o foco dessa unidade é o conceito de território, com foco na geografia política e, principalmente, na geopolítica. A abordagem do território não apresenta um autor específico, mas com conhecimento de geografia política e observando que o território é retratado como a união de espaço e poder, é possível observar que o conceito utilizado tem um forte viés da abordagem de Claude Raffestin, geógrafo com viés naturalista e que acreditava que o território é formado a partir de relações de poder e que o espaço é anterior ao território. Na mesma introdução outros geógrafos e outras correntes são citados diretamente. O geógrafo Milton Santos, pertencente à corrente da geografia crítica, é citado, mostrando que para ele, o território era a junção da população e do chão, dizendo que o território é a base para todo trabalho e desenvolvimento. Ainda na mesma sessão, Friedrich Ratzel, o pai da Geopolítica e conhecido por sua geografia determinista, é citado como precursor da área a ser estudada nessa parte do livro. $\mathrm{E}$ 
mostrando que o livro seguirá diversas linhagens geográficas, o texto também cita Yves Lacoste, conhecido por ter obras pioneira da geografia crítica, e Josué de Castro, que lançou um livro criticando explicações deterministas para certos eventos, como a fome. A introdução do segundo Conteúdo Estruturante está relacionada à corrente Humanística e Cultural, essa corrente foi usada para tratar de assuntos como a cultura em si e a demografia. Não há autores citados e nem conceitos principais apresentados diretamente na introdução, mas no decorrer da unidade novos conceitos, além do território, são apresentados, o de paisagem e de lugar.

\subsection{TERRITÓRIO E SOCIEDADE NO MUNDO GLOBALIZADO: ENSINO MÉDIO}

Ao final de cada volume, há um manual que visa direcionar o professor para que ele possa ter uma melhor relação com o livro, nessa parte é dito que no livro didático terá diversas correntes de pensamento pois essa diversidade ajudaria bastante na compreensão da geografia como um todo pois cada corrente tem afinidade com um conceito específico, essa sessão mostra que os principais destaques do livro são o positivismo e a geografia crítica. Durante o Volume 1, no capítulo 1, é apresentado o conceito de espaço geográfico, que seria o conjunto de elementos naturais e construídos em movimento permanente, o espaço geográfico, na visão dos autores do livro é a união no espaço de elementos materiais e as relações que permeiam as sociedades como um todo. Na mesma parte, também há a explicação do que seria a paisagem geográfica para o geógrafo crítico Milton Santos, a paisagem seria tudo que se vê e se percebe em uma porção do espaço. Ainda no mesmo capítulo, o conceito de meio geográfico também é apresentado, sendo ele um ambiente onde a sociedade desenvolve suas relações e desenvolve suas tecnologias, apresentando também termos caros para Milton como o meio natural, meio técnico e meio técnico-científico-informacional. No Volume 2, no capítulo 1, o território é definido como um espaço apropriado por indivíduos ou pelo Estado, esse espaço é mantido, definido e limitado através de relações de poder. No Volume 3, no capítulo 4, o conceito de lugar é definido como um espaço físico onde o indivíduo convive, o lugar tem diversos significados e cada um deles depende da pessoa pois é um conceito baseado em vivencia e significância, o texto deixa claro que o conceito é baseado no sentimento de pertencimento e percepção. Outros conceitos chegam a ser apresentadas no livro mas não recebem aprofundamento necessário para uma definição clara, lendo com conhecimento prévio é possível identificar linhas e a origem dos conceitos, mas sem conhecimento prévio não é possível definir. 


\section{ABORDAGENS DE TEMÁTICAS AFRICANAS, AFROBRASILEIRAS E} REPRESENTATIVIDADE DE AMBAS NOS LIVROS DIDÁTICOS

\subsection{GEOGRAFIA: ENSINO MÉDIO}

Já no capítulo 1, “O Brasil Podia Ser Diferente?”, aparece um possibilidade de retratar a cultura africana e afro-brasileira, mas o livro que na Carta do Secretário diz que o livro foi formulado para suprir carências históricas no material didático do ensino médio e que na Carta ao Aluno diz que há uma preocupação em passar e valorizar conhecimento científico, filosófico e artístico, perdeu uma excelente oportunidade na primeira página do primeiro capitulo, já que decidiu falar de diversidade, colocar uma imagem representando a diversidade brasileira e representar a cultura indígena e afrobrasileira com personagens embranquecidos.

Embora tenha 3 representações de cultura africanas/afro-brasileira de 6, a capoeira, o candomblé e o samba estão sendo representado por gravuras embranquecidas, sendo difícil de distinguir, por exemplo, personagens naturalmente racializados do personagem que representa a cultura relacionada à região Sul do Brasil que tem fortes influencias da Europa. Nesse mesmo capítulo a construção territorial do Brasil é explicada, contando desde o Tratado de Tordesilhas até a transformação da colônia portuguesa em república. Apesar do livro ter acertado no uso de aspas para falar de quando o Brasil "nasceu” e que os indígenas “cederam” o espaço para a Coroa portuguesa e para a Coroa Espanhola, o livro peca muito por não considerar o território indígena como território pois as organizações indígenas não se encaixam na visão eurocentrista do que seria um "Estado”, a tentativa de falar de forma mais consciente sobre a escravidão faz com que o assunto não seja abordado com deveria, sendo pouco citado durante o texto. O livro reconhece que a população africana povoou o território colonial e permaneceu no litoral, onde se desenvolveu a economia brasileira com base na escravidão. 


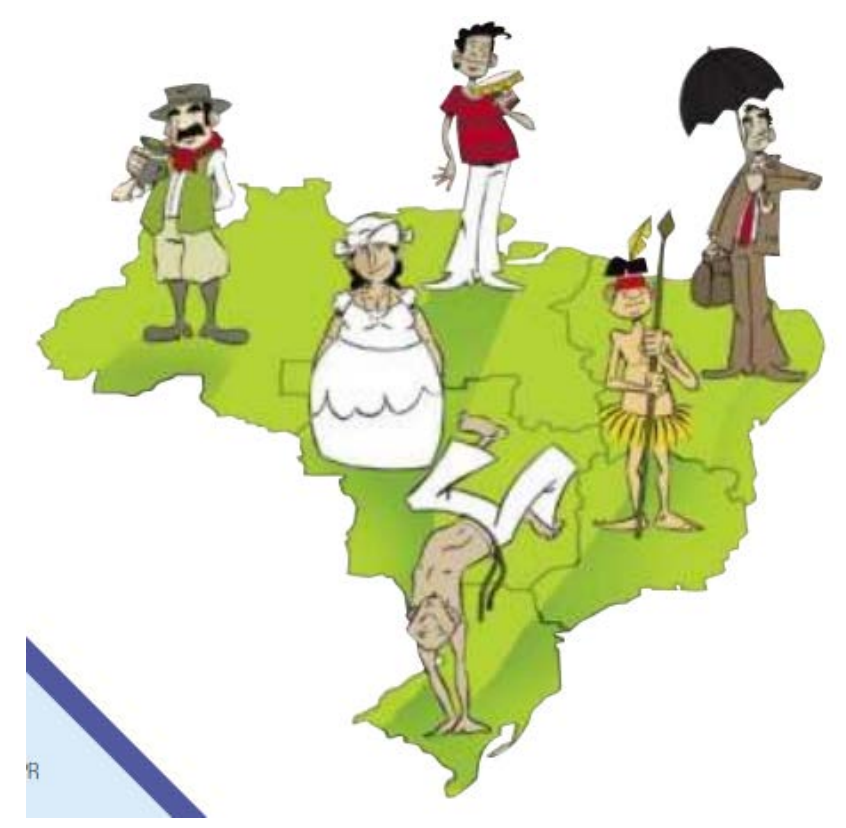

IMAGEM 5: Gravura representando a “diversidade” brasileira. Página 19 do livro GEOGRAFIA: ENSINO MÉDIO (2007).

No capítulo 2, ao falar dos "guetos” e periferias, o livro didático cita os guetos norteamericanos e os guetos criados na África do Sul durante o período do Apartheid, no glossário presente na página 48 existe uma explicação de 6 linhas sobre o que foi o Apartheid e sua realidade.

Na introdução do Conteúdo Estruturante que aborda cultura e demografia, o livro didático fala, sem dados, que a população negra é a mais pobre do país e que por causa disso vive em situações precárias. No capítulo 6, após falar de uma forma muito superficial da migração relacionada aos

exescravos no Brasil e apresentar um texto que fala sobre a imigração de árabes e negros para a França, o livro mostra uma charge que deveria falar sobre a migração de famílias com menos dinheiro. O que poderia ter de errado nessa charge? Os personagens tem o mesmo tom de pele que os personagens da primeira imagem, mas dessa vez, por acaso ou não, existe um sombreamento que faz os personagens com menos dinheiro terem pele mais escura do que o vendedor na primeira parte da charge, onde também mostra que a mãe grávida tem cabelo cacheado, esse sombreamento desaparece na segunda parte da charge quando eles são mostrados de costas olhando para o rio poluído e o cabelo evidencia que as crianças e o pai têm traços herdados de africanos. Então há duas linhagens de pensamento aqui, ou até agora (página 144) nenhum personagem negro foi inserido, ou foi inserido agora com estereótipo de pobreza e com o branqueamento. A charge se trata, basicamente, de um pai de família falando para um vendedor que quer uma casa e o vendedor diz que tem uma casa pra eles de frente ao Tietê, e logo em seguida mostra a família em uma casa de madeira olhando para um rio cheio de poluentes como esgoto e lixo. 

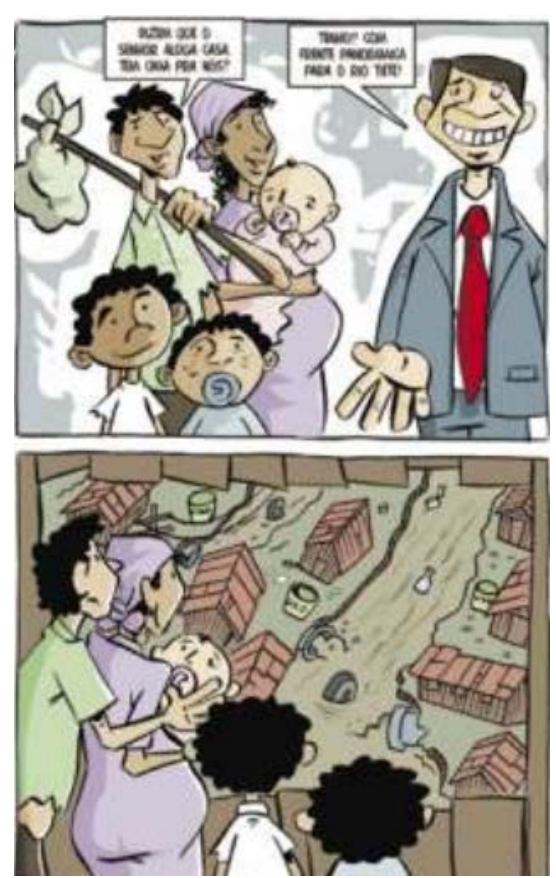

IMAGEM 6: Charge que aborda migração para população sem dinheiro. Página 144 do livro GEOGRAFIA: ENSINO MÉDIO (2007).

No capítulo 7, que aborda a questão de conflitos, outra charge é mostrada, e dessa vez com personagens indiscutivelmente negros, sendo assim, a primeira vez que se pode afirmar com certeza que houve aparição de negros no livro didático.
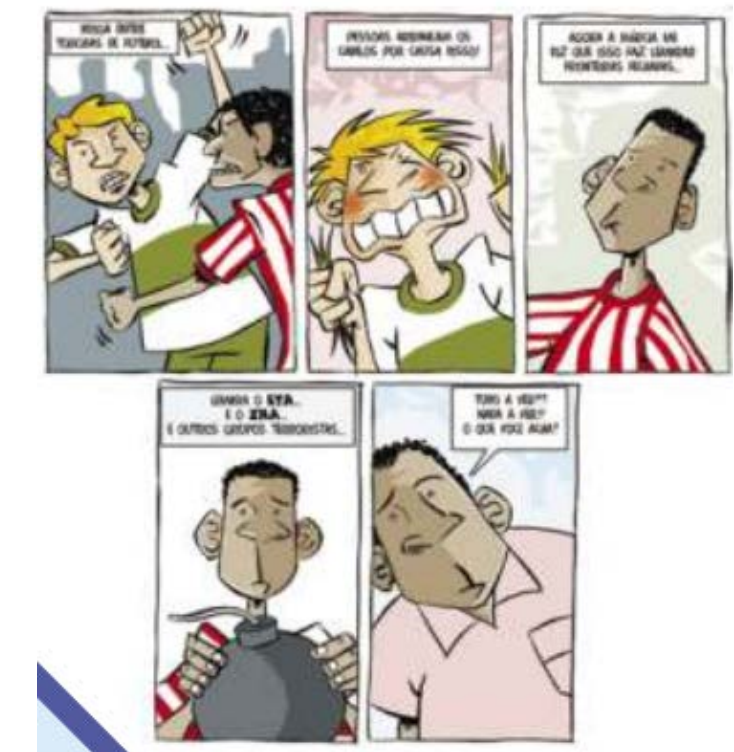

IMAGEM 7: Charge que aborda conflitos. Página 119 do livro GEOGRAFIA: ENSINO MÉDIO (2007). 


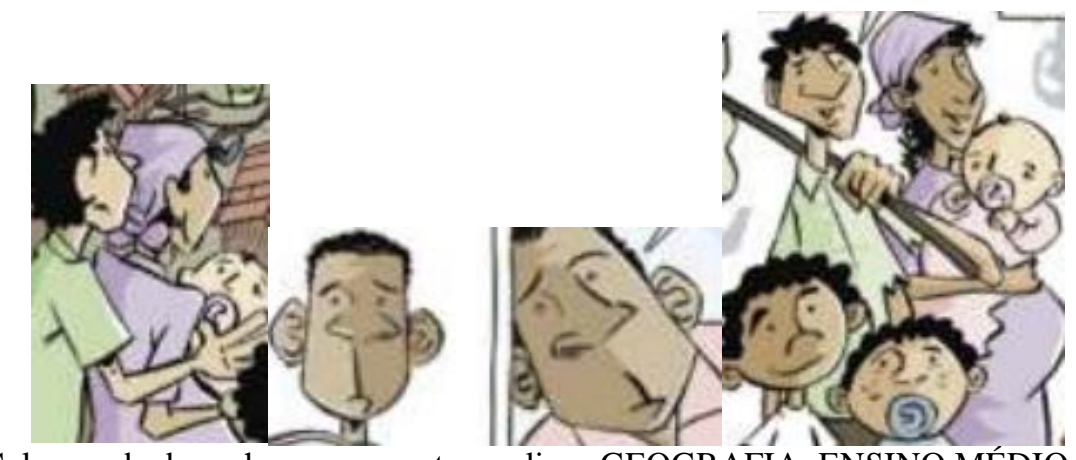

IMAGEM 8: Colagem de duas charges presentes no livro GEOGRAFIA: ENSINO MÉDIO (2007).
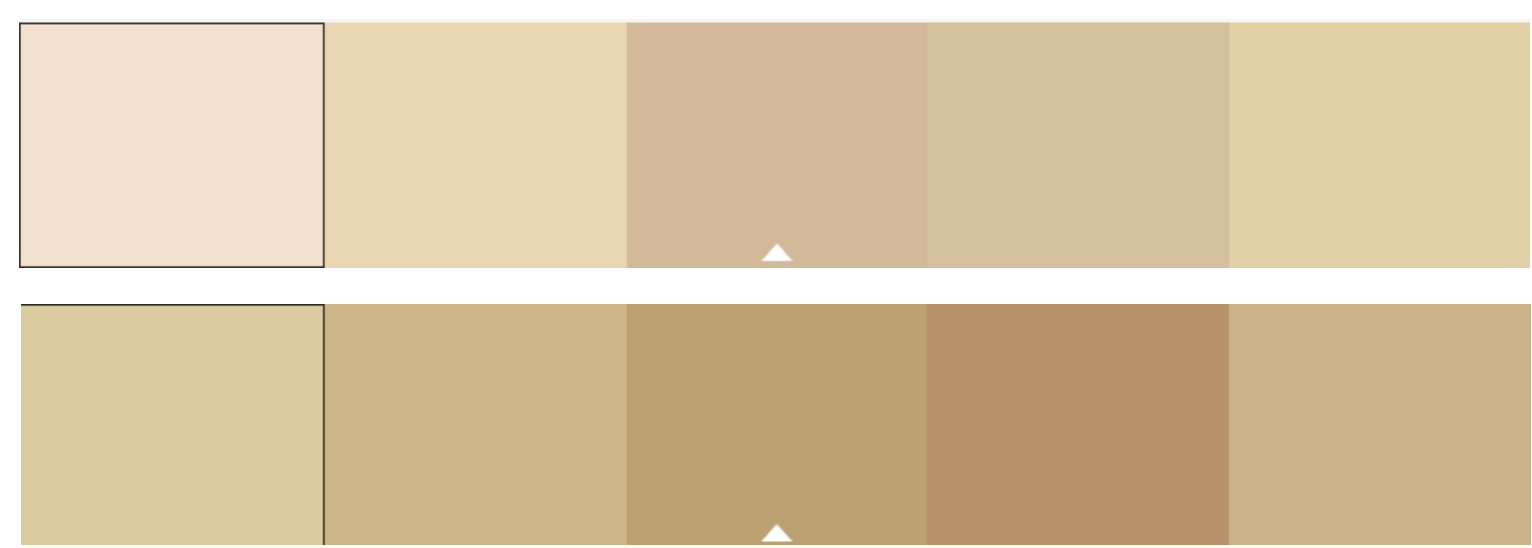

IMAGEM 9: Em cima: a cor mais clara (sem sombra) dos personagens da Imagem 7. Cada quadrado representa respectivamente: o vendedor, o pai, a mãe, o irmão mais velho e o irmão do meio. Em baixo: a cor mais escura (com efeito da sombra) dos personagens da Imagem 7. Cada quadrado representa respectivamente: o vendedor, o pai, a mãe,

o irmão mais velho e o irmão do meio. Paleta de cores feita no site: https://color.adobe.com/pt/create/color-wheel

Comparando as duas últimas charges e usando a ferramenta “conta gotas” é possível ver que existe sim uma paleta de cores específica para retratar os personagens, na primeira charge não é tão perceptível, mas o vendedor é mais claro que os personagens com menos dinheiro, na segunda charge é mais evidente a diferença de cores entre o personagem branco e personagens pretos. Quando colocamos os personagens pretos da segunda charge ao lado dos personagens da primeira charge, é possível sim entender porque há a primeira impressão de que os personagens da primeira charge são negros.

Ainda no capítulo 7, o livro aborda que os países ricos do Norte fecham a fronteira para os países pobres, esse fechamento de fronteiras tem como propósito deixar de fora "outros” que os governantes acham que podem colapsar o sistema dos países, e o livro deixa explicito que os “outros” geralmente são negros.

Na introdução do Conteúdo Estruturante, que trata sobre economia e informações, o livro didático diz que o meio técnico-científico-informacional não se espalha nos territórios de forma igual, explicitando que as “favelas africanas”, assim como alguns outros locais, são áreas 'desconectadas'. 
A imagem de introdução do capítulo 10, traz um mercado onde a paisagem e ocupada com pessoas negras.

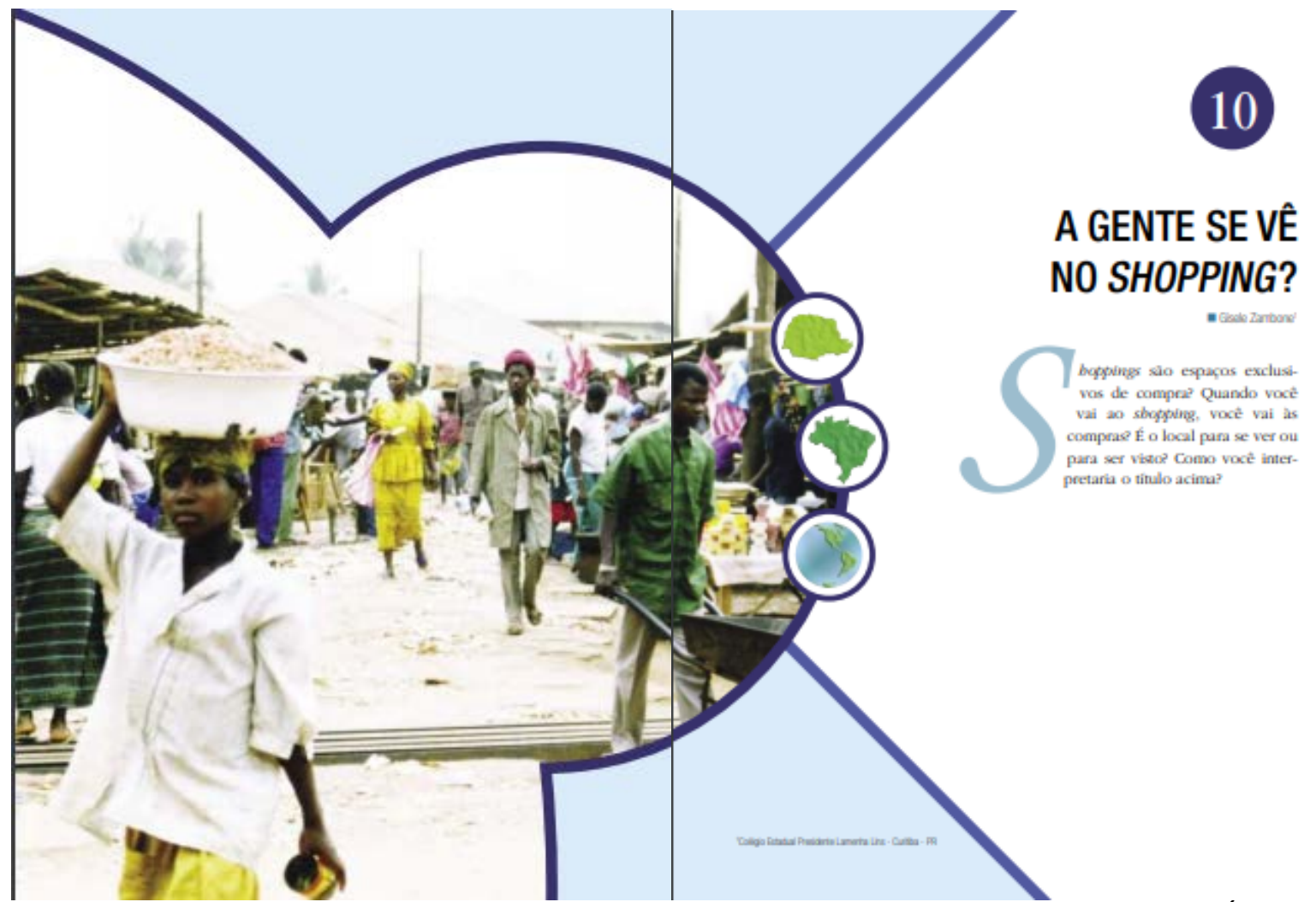

IMAGEM 10: Foto de um mercado movimentado. Páginas 162 e 163 do livro GEOGRAFIA: ENSINO MÉDIO (2007).

O capítulo 15 é responsável por abordar a fome, o capítulo abre com uma charge onde há pessoas negras representadas e essa é a última imagem com referência negra do livro. É possível concluir que não houve nenhum negro retinto sendo representado. Nesse mesmo capítulo é dito que a fome é um problema grave entre países pobres, e uma pesquisa sem fonte explicita diz que no Brasil a situação é ruim, mas na Ásia Meridional e na África é pior.
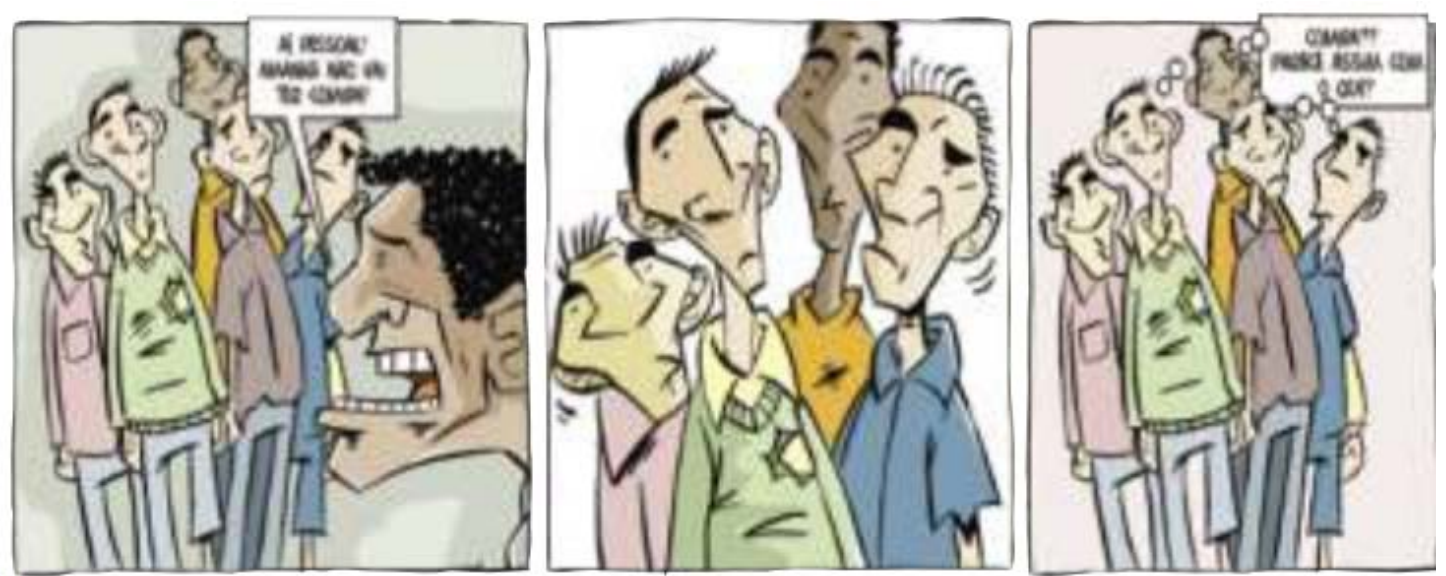

IMAGEM 11: Charge sobre a fome. Página 199 do livro GEOGRAFIA: ENSINO MÉDIO (2007). 


\subsection{TERRITÓRIO E SOCIEDADE NO MUNDO GLOBALIZADO: ENSINO MÉDIO}

O Volume 1, tem mais gravuras e desenhos do que fotografias, seu foco é a paisagem então há mais imagens relacionadas ao clima, à geologia, plantas, animais, etc, mas, apesar de ter foco nos aspectos físicos da Terra e o estudo do espaço absoluto, esse volume traz algumas representações que interessam a esse artigo.

Na unidade 1, responsável por falar sobre a era da informação e a cartografia, é explicitado que a projeção de Mercator foi desenvolvida na época em que a Europa estava colonizando a Ásia, a África e a América, o texto também diz que a interpretação da projeção dá a entender que o mapa reforça que existe uma superioridade e uma grandeza dos países do Norte em relação aos países do Sul, mas que não dá pra afirmar isso com toda certeza. Na mesma página, o livro didático fala sobre

Peters, cartógrafo alemão que não gostava da projeção anterior e queria uma projeção que, embora um pouco distorcida, representasse a realidade dos continentes explorados, então ele entregou um trabalho com sua proposta, onde dá pra perceber que os “países do Sul” não eram menores nem submissos aos outros.

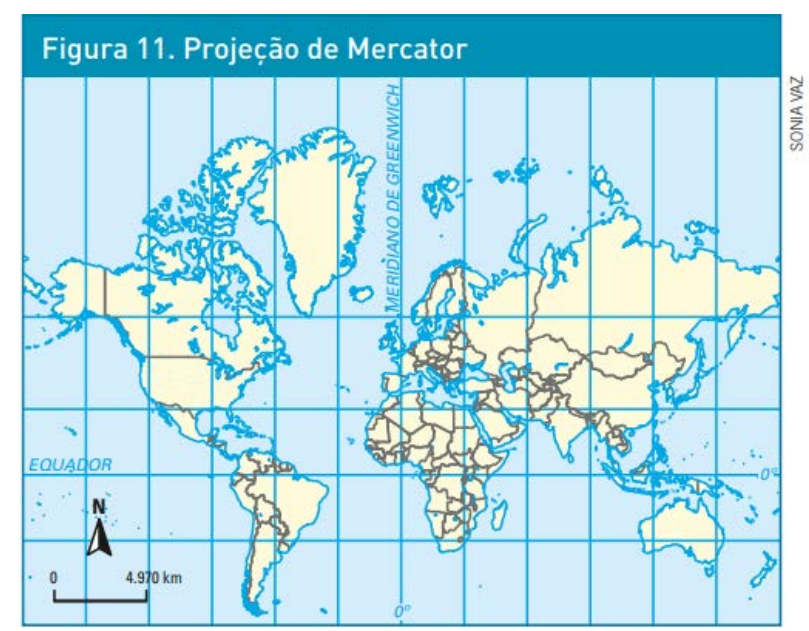

IMAGEM 12: Representação da Projeção de Mercator. Página 50 do Volume 1 do livro TERRITÓRIO E SOCIEDADE NO MUNDO GLOBALIZADO: ENSINO MÉDIO (2016).

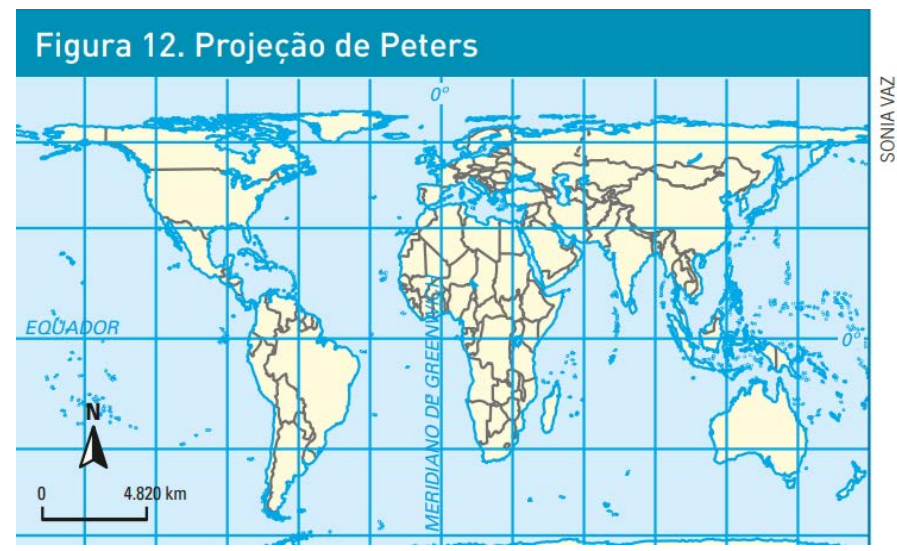

IMAGEM 13: Representação da Projeção de Peters. Página 50 do Volume 1 do livro TERRITÓRIO E SOCIEDADE NO MUNDO GLOBALIZADO: ENSINO MÉDIO (2016). 
No capítulo 4, responsável por explicar os fenômenos geológicos, há uma fotografia de uma arte egípcia que representa a colheita de trigo, e o interessante é que o livro reconhece a civilização egípcia como uma das primeiras grandes civilizações agrícolas.

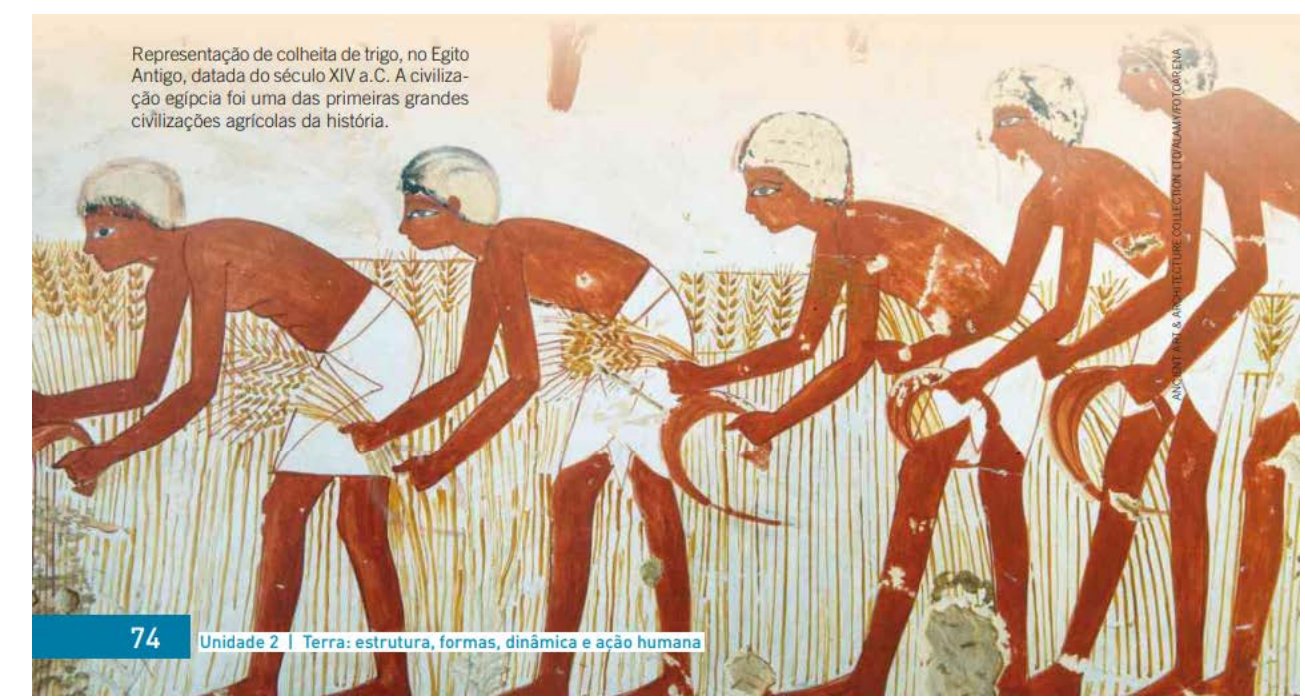

IMAGEM 14: Representação de colheita de trigo no Egito Antigo. Página 74 do Volume 1 do livro TERRITÓRIO E SOCIEDADE NO MUNDO GLOBALIZADO: ENSINO MÉDIO (2016).

Na unidade 3, responsável pelo clima e formações vegetais, há menções às comunidades quilombolas, formadas por descendentes de africanos escravizados que se rebelaram e criaram locais de refúgio e resistência social e política, e às comunidades caiçaras, formadas pelos descendentes de indígenas miscigenados com brancos e pretos que vivem da pesca e da agricultura de subsistência.

No capítulo 10, responsável por falar sobre gestão, características e conflitos relacionados à hidrosfera, há uma imagem de uma senhora negra coletando água em um açude.

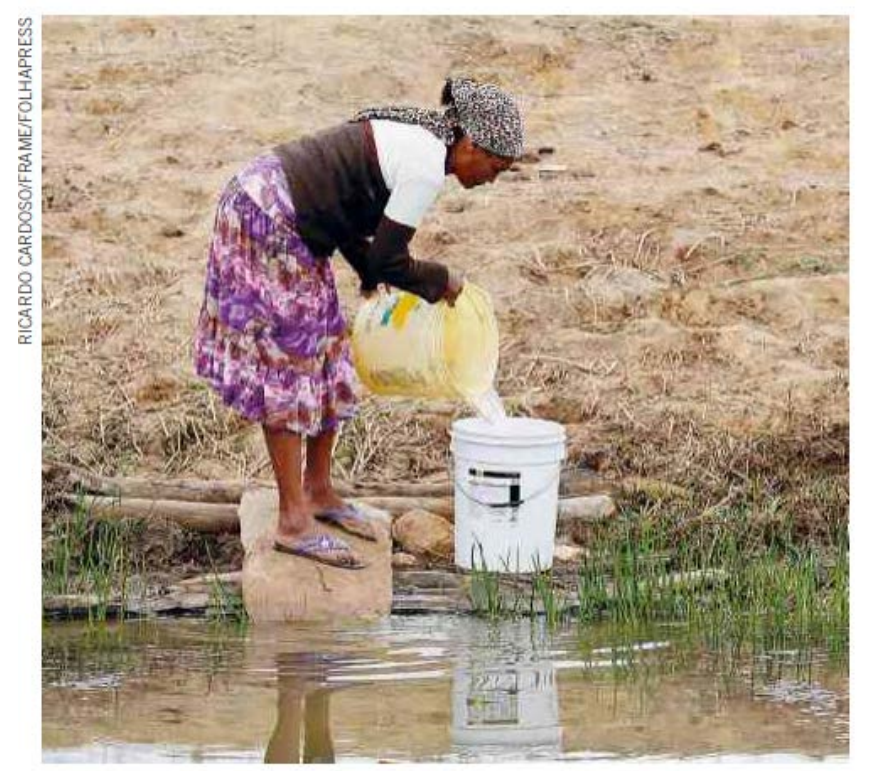

IMAGEM 15: Mulher coleta água em açude, em Vitória da Conquista (BA), 2012. Página 187 do Volume 1 do livro TERRITÓRIO E SOCIEDADE NO MUNDO GLOBALIZADO: ENSINO MÉDIO (2016). 
No final da Unidade 5, responsável por falar de natureza, sociedade e meio ambiente, há uma foto de crianças negras carregando lenha para servir de fonte de energia.

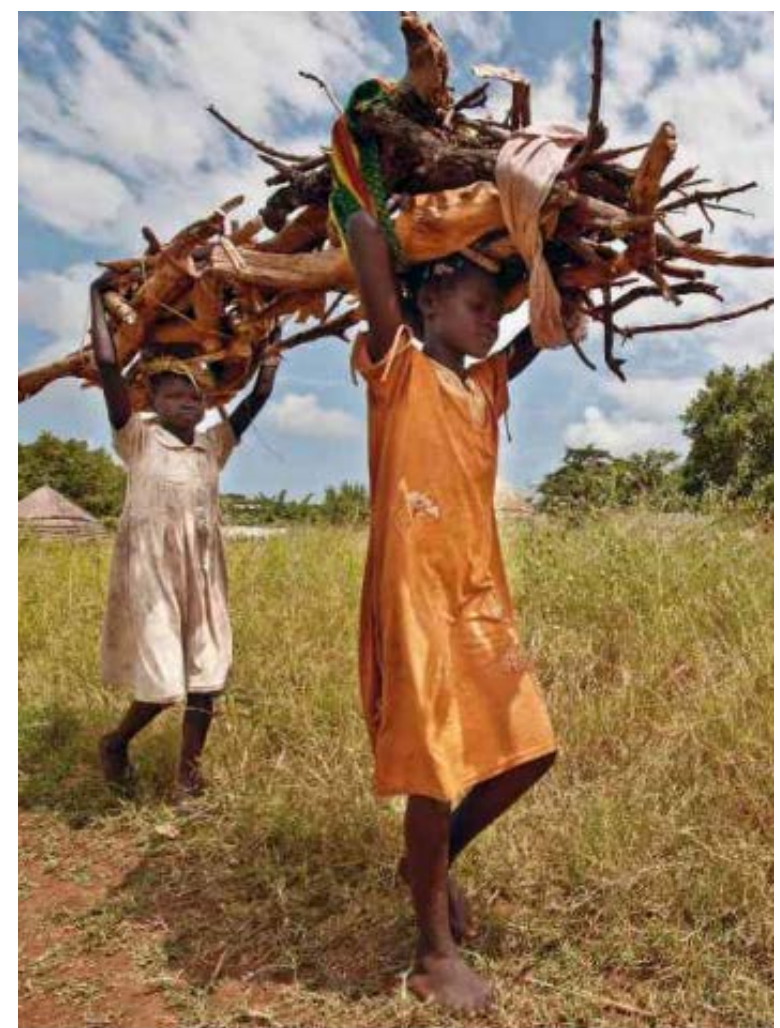

IMAGEM 16: Crianças recolhem lenha para usar como fonte de energia em suas casas, no Sudão do Sul, 2011. Página 238 do Volume 1 do livro TERRITÓRIO E SOCIEDADE NO MUNDO GLOBALIZADO: ENSINO MÉDIO (2016).

No capítulo 13, responsável por falar sobre problemas ambientais de nível global, há uma foto de um senhor negro ao lago de carcaças, mostrando como a seca atingiu a região.

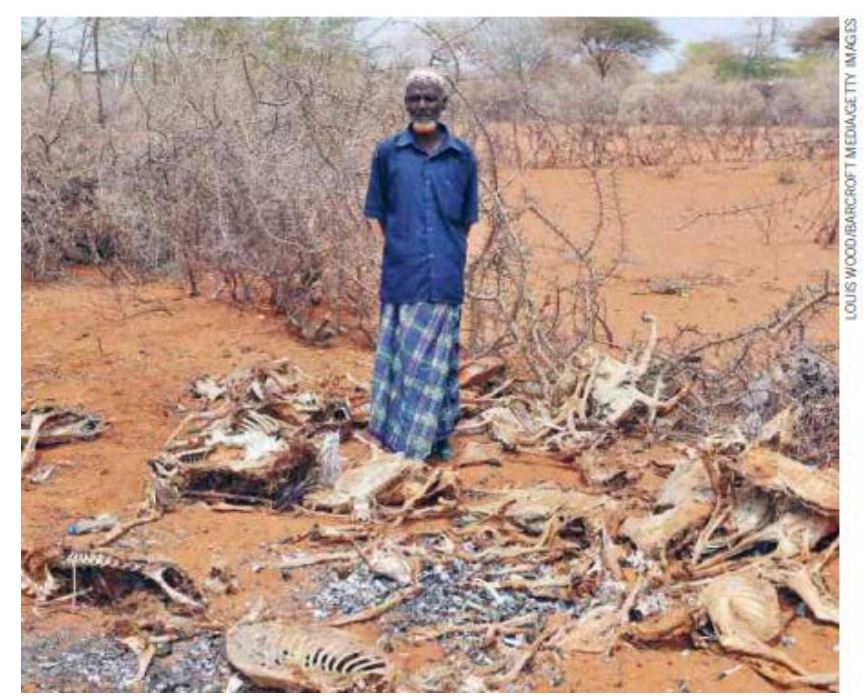

IMAGEM 17: Homem mostra traços das consequências da seca, como vegetação queimada e esqueletos de animais, em Mandera (Quênia), 2011. Página 247 do Volume 1 do livro TERRITÓRIO E SOCIEDADE NO MUNDO GLOBALIZADO: ENSINO MÉDIO (2016).

No Volume 2, com foco na história e na geopolítica, o livro também trás representatividade e foco nos assuntos relacionados ao que é conhecido como “negritude”, começando pela capa, que é 
estampada por uma mulher negra. O capítulo 1, responsável por falar do mundo na Guerra Fria, aborda as lutas anticoloniais e o pan-africanismo. O texto discorre sobre movimentos fortes que pautavam a libertação definitiva da África dos seus colonizadores e mostra duas imagens, a primeira de uma arte de um pintor chinês e a outra é um mapa relacionado ao processo de descolonização após 1945.

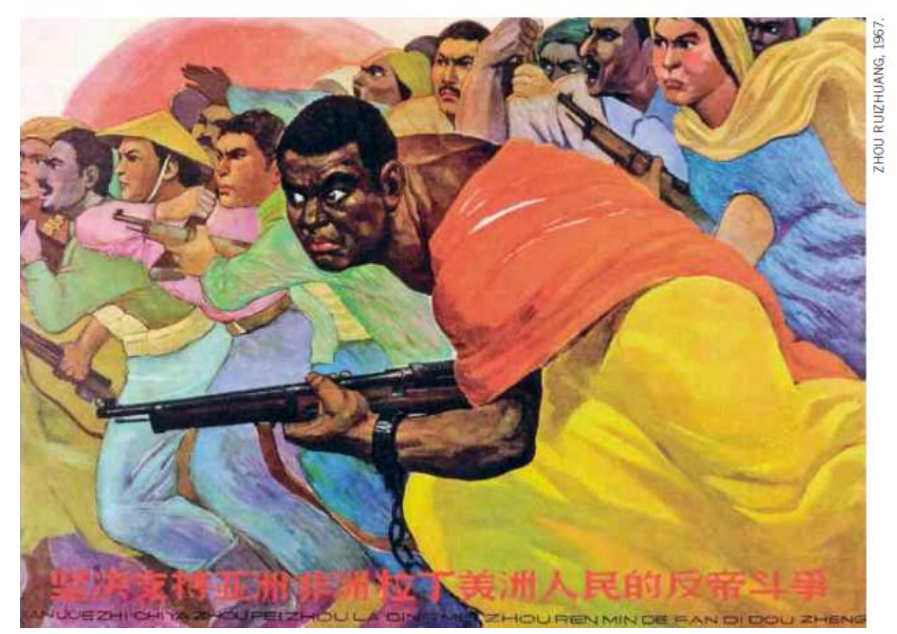

IMAGEM 18: Arte do chinês Zhou Ruizhuang. Na imagem está escrito: “Apoiar com determinação a luta antiimperialista dos povos asiáticos, africano e da América Latina”. Página 29 do livro TERRITÓRIO E SOCIEDADE NO MUNDO GLOBALIZADO: ENSINO MÉDIO VOLUME 2 (2016).

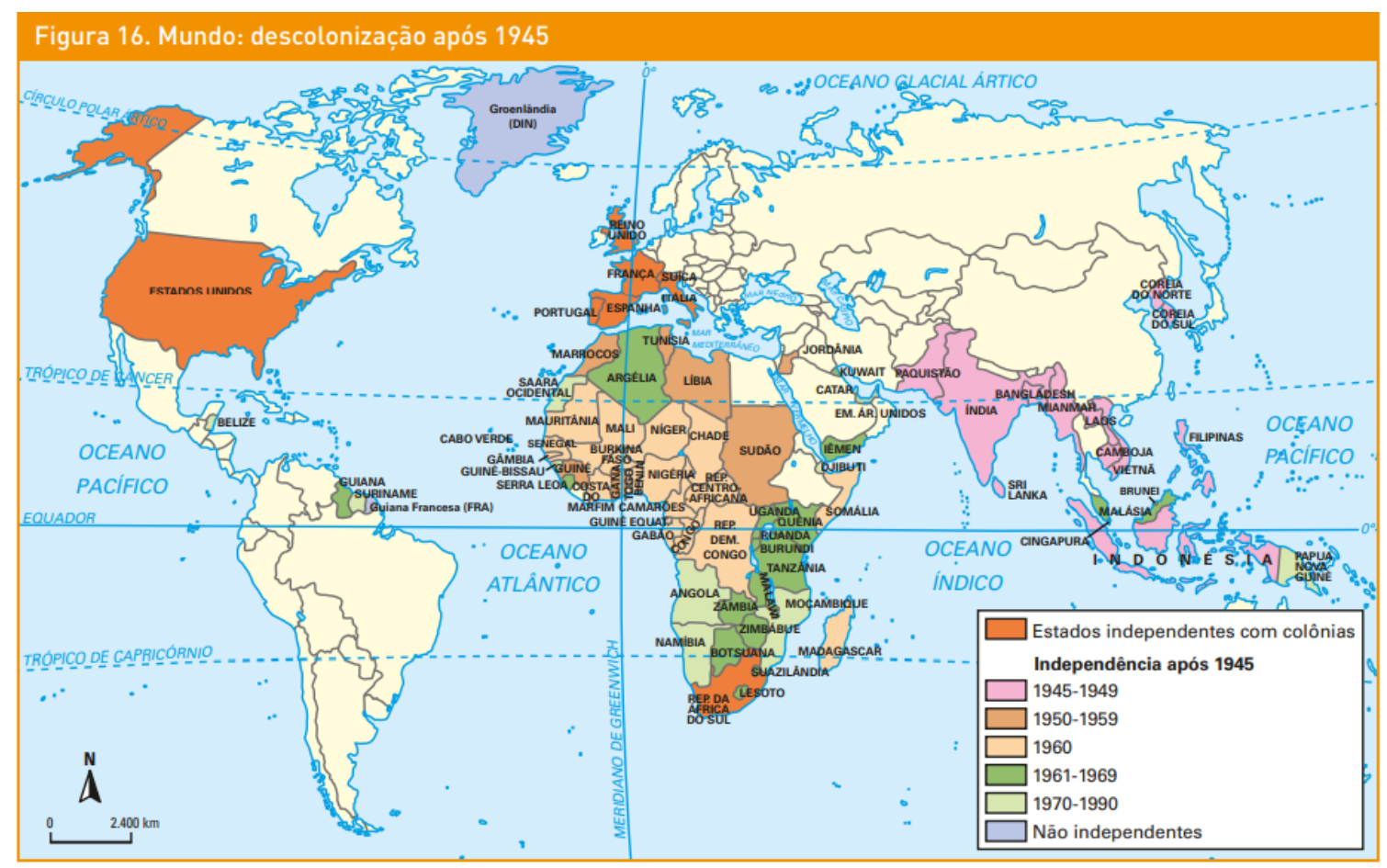

IMAGEM 19: Mapa mostrando o processo de independência dos países após o ano 1945. Página 30 do livro TERRITÓRIO E SOCIEDADE NO MUNDO GLOBALIZADO: ENSINO MÉDIO VOLUME 2 (2016). 
No capítulo 3, que fala sobre globalização e redes da economia mundial, há duas imagens com pessoas negras utilizando computadores. No capítulo 12, responsável por falar dos espaços agrários no mundo, é mostrada a situação agropecuária na África, onde essa atividade ainda é uma das principais. Também há uma imagem de uma mulher africana com seu bebê.

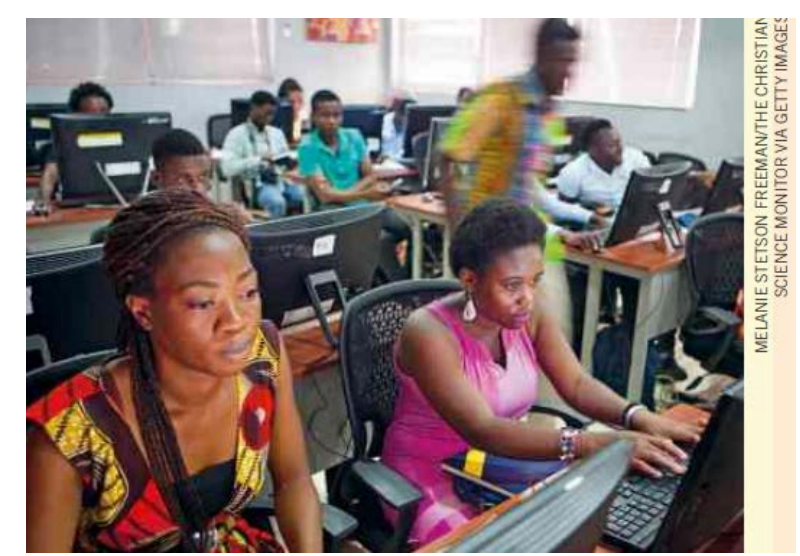

IMAGEM 20: Estudantes utilizam computadores conectados à internet em workshop de jornalismo em Acra (Gana), 2014. Página 67 do livro TERRITÓRIO E SOCIEDADE NO MUNDO GLOBALIZADO: ENSINO MÉDIO VOLUME 2 (2016).

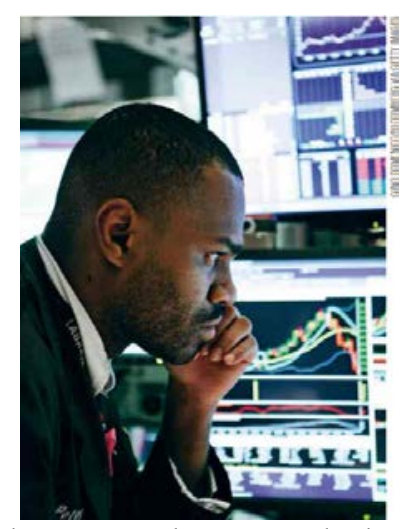

IMAGEM 21: Negociador do mercado de ações observa perplexo a queda dos valores das ações na Bolsa de Valores de Nova York (Estados Unidos), na crise financeira, em novembro de 2008. Página 83 do livro TERRITÓRIO E SOCIEDADE NO MUNDO GLOBALIZADO: ENSINO MÉDIO VOLUME 2 (2016). 


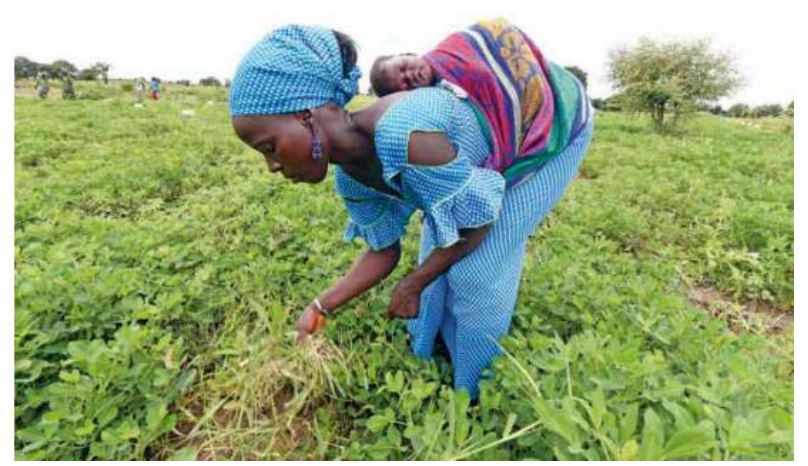

IMAGEM 22: Agricultora carrega seu bebê enquanto trabalha em Daga Birame (Senegal), 2015. Página 263 do livro TERRITÓRIO E SOCIEDADE NO MUNDO GLOBALIZADO: ENSINO MÉDIO VOLUME 2 (2016).

No volume 3, a primeira unidade é exclusiva para assuntos relacionados à etnia e diversidade. Na página 24 há um item falando sobre afrodescendentes, o livro fala sobre a origem dos africanos trazidos como escravos, quantos foram aproximadamente, quais os papeis que desempenharam aqui, a realidade de africanos e afro-brasileiros após o fim oficial da escravidão e a realidade deles nos dias mais atuais (levando em consideração que o livro é de 2016). O livro propõe duas atividades aos alunos, analisar criticamente duas charges do artista negro Mauricio Pestana presentes na obra intitulada “Racista Eu!? De jeito nenhum...”.

O livro apresenta dados sobre desigualdade no Brasil segundo a cor de pele em 2014, levando em consideração a proporção total da população total do Brasil, a tabela apresenta a porcentagem de negros e brancos em relação ao total com problemas relacionados à escola e ao trabalho, mostrando que o racismo ainda continua em vigência.

Após mostrar a desigualdade em que afrodescendentes estão submersos, o livro aborda a questão de ações afirmativas e a questão das cotas, ambas servem como uma tentativa de empoderar e dar uma nova realidade a um grupo social que teve tudo negado durante séculos, essas formas de resistência ao sistema racista acaba fazendo link com a forma de resistência negra mais antiga no país, os quilombos. O livro aborda os quilombos de forma aberta, apesar de pecar por não deixar explicito que eles foram um território de resistência e identidade, e deixar no ar que os territórios quilombolas foram simplesmente cedidos, o texto explicita a dificuldade que algumas terras quilombolas tem de conseguir titulação definitiva e a dificuldade que os quilombolas tem em ter acesso à recursos essenciais e garantir a perseverança de suas existências. Além da educação e do trabalho, a população afrodescendente sofre com outro problema: a violência, há uma tabela baseada no Mapa da Violência de 2015 que mostra a realidade de homicídios por arma de fogo comparando brancos e negros em dois anos diferentes. 


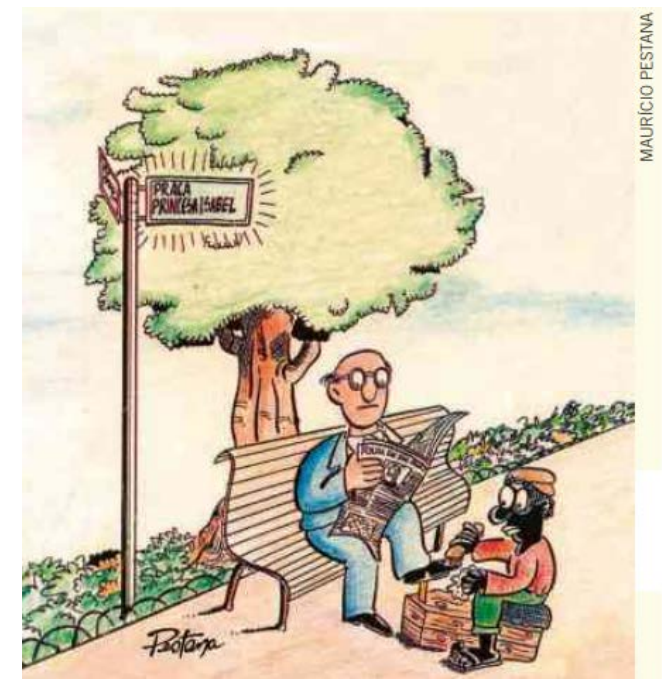

IMAGEM 23: PESTANA, Maurício. Racista Eu!? De jeito nenhum... São Paulo: Escala, 2001. p. 22. Página 24 do livro TERRITÓRIO E SOCIEDADE NO MUNDO GLOBALIZADO: ENSINO MÉDIO VOLUME 3 (2016).

\begin{tabular}{|c|c|c|c|}
\hline \multicolumn{4}{|c|}{ Brasil: desigualdade segundo a cor da pele - 2014} \\
\hline & Brasil & Brancos & Negros* \\
\hline População total & 203,2 milhões** & $45,5 \%$ & $53,6 \%$ \\
\hline $\begin{array}{l}\text { Proporção da população de } 10 \text { anos ou mais de } \\
\text { idade entre os } 10 \% \text { com menores rendimentos. }\end{array}$ & - & $22,8 \%$ & $76,0 \%$ \\
\hline $\begin{array}{l}\text { Proporção da população de } 10 \text { anos ou mais de } \\
\text { idade entre o } 1 \% \text { com maiores rendimentos. }\end{array}$ & - & $79,6 \%$ & $17,4 \%$ \\
\hline $\begin{array}{l}\text { Proporção dos estudantes de } 18 \text { a } 24 \text { anos de } \\
\text { idade que frequentam o ensino superior. }\end{array}$ & $58,5 \%$ & $71,4 \%$ & $45,5 \%$ \\
\hline $\begin{array}{l}\text { Proporção da população com } 16 \text { anos ou mais } \\
\text { idade ocupada em emprego informal. }\end{array}$ & $42,3 \%$ & $35,3 \%$ & $48,4 \%$ \\
\hline
\end{tabular}

Fonte: IBGE. Síntese de Indicadores Sociais. Uma análise das condições de vida da população brasileira 2015. Disponível em: <http://biblioteca.ibge.gov.br/>. Acesso em: fev. 2016.

IMAGEM 24: Tabela com indicadores sociais. Página 25 do livro TERRITÓRIO E SOCIEDADE NO MUNDO GLOBALIZADO: ENSINO MÉDIO VOLUME 3 (2016).

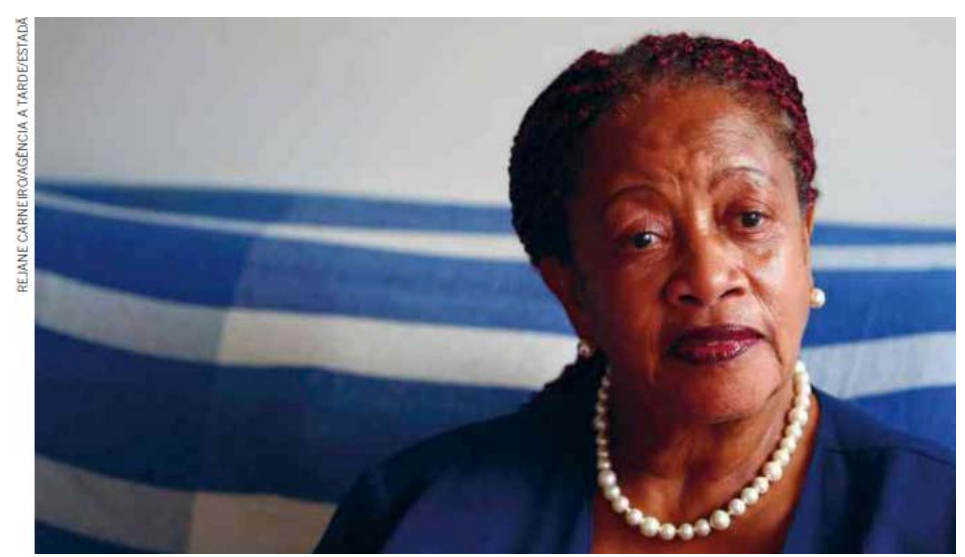

IMAGEM 25: Luislinda Valois, a primeira juíza afrodescendente do Brasil, a primeira também a proferir a primeira sentença como o racismo. Página 25 do livro TERRITÓRIO E SOCIEDADE NO MUNDO GLOBALIZADO: ENSINO MÉDIO VOLUME 3 (2016). 


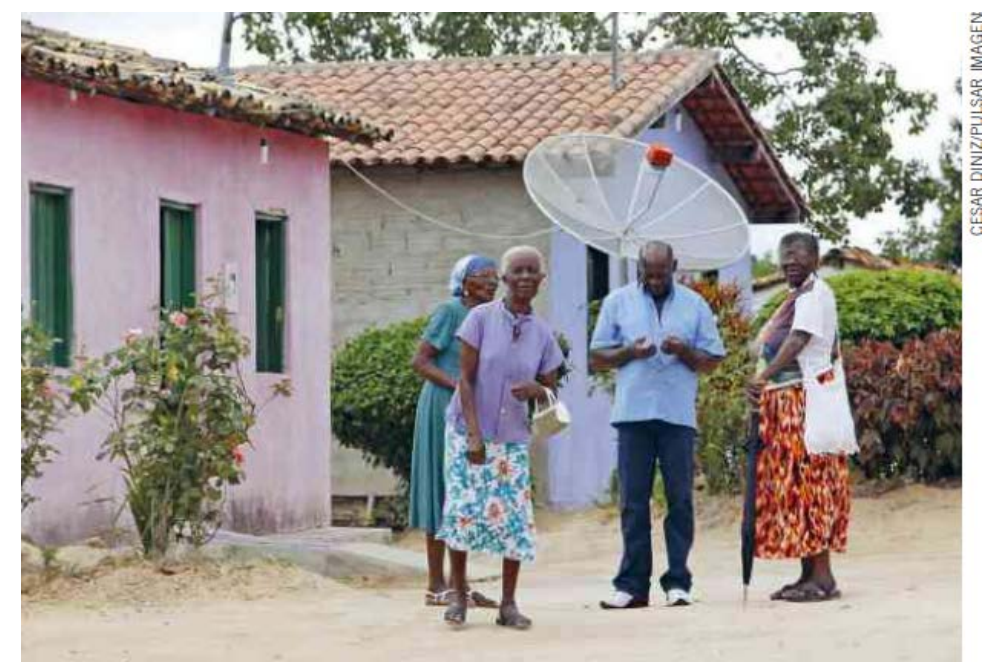

IMAGEM 26: Habitantes de Rio de Contas (BA) reúnem-se para a festa de São Sebastião na comunidade remanescente do Quilombo da Barra, em 2014. Página 27 do livro TERRITÓRIO E SOCIEDADE NO MUNDO GLOBALIZADO: ENSINO MÉDIO VOLUME 3 (2016).

\begin{tabular}{|l|c|c|c|c|}
\hline \multirow{2}{*}{ Região } & \multicolumn{3}{|c|}{ Homicidios por armas de fogo } \\
\cline { 2 - 5 } & \multicolumn{2}{|c|}{ Branca } & 2003 & 2012 \\
\cline { 2 - 5 } & 2003 & 2012 & 1.370 & 3.433 \\
\hline Norte & 277 & 385 & 6.228 & 13.647 \\
\hline Nordeste & 905 & 1.215 & 10.516 & 7.824 \\
\hline Sudeste & 8.530 & 4.346 & 599 & 1.084 \\
\hline Sul & 2.826 & 3.923 & 1.578 & 2.958 \\
\hline Centro-0este & 686 & 763 & 20.291 & 28.946 \\
\hline Brasil & 13.224 & 10.632 & & \multicolumn{2}{c|}{ Negra } \\
\hline
\end{tabular}

IMAGEM 27: WAISELFISZ, Julio Jacobo. Mapa da Violência 2015: os novos padrões da violência homicida no

Brasil. Brasília: Secretaria de Políticas de Promoção da Igualdade Racial. Página 28 do livro TERRITÓRIO E SOCIEDADE NO MUNDO GLOBALIZADO: ENSINO MÉDIO VOLUME 3 (2016).

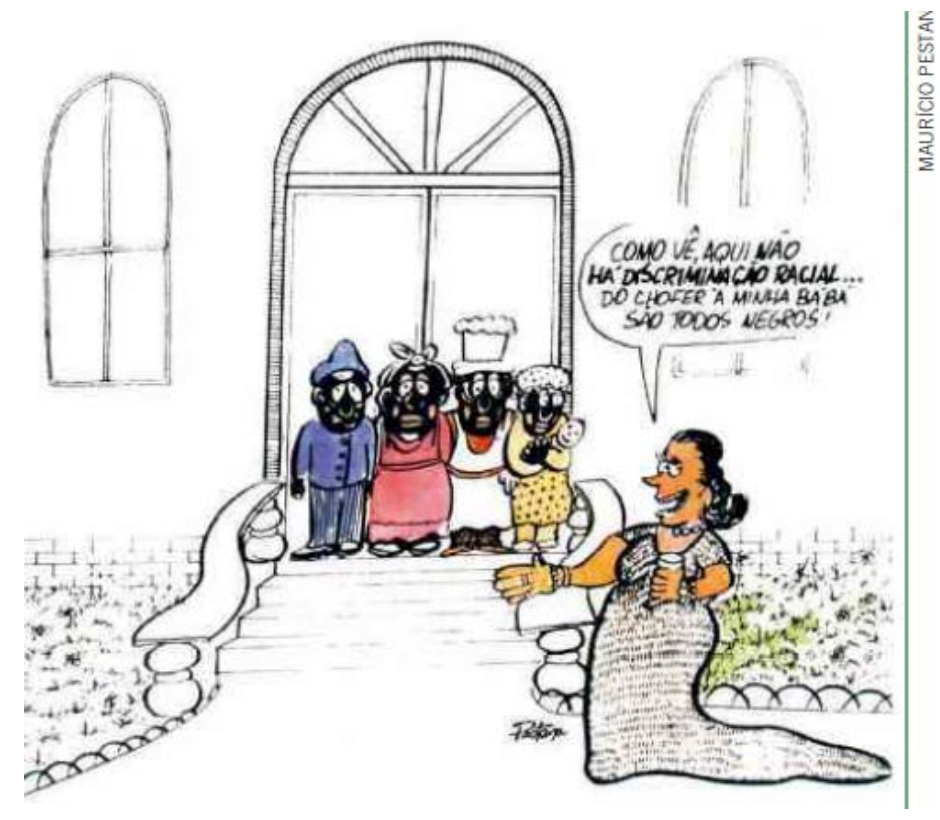

IMAGEM 28: WAISELFISZ, Julio Jacobo. Mapa da Violência 2015: os novos padrões da violência homicida no 
Brasil. Brasília: Secretaria de Políticas de Promoção da Igualdade Racial. Página 30 do livro TERRITÓRIO E SOCIEDADE NO MUNDO GLOBALIZADO: ENSINO MÉDIO VOLUME 3 (2016).

Até aqui, esse livro citou a África e a realidade afro-brasileira de diversos modos, e sempre da melhor forma possível, apesar de que há momentos em que é possível sentir que falta alguma coisa. O conhecimento do território, do clima, da geomorfologia, da hidrografia, da vegetação, a disponibilização de dados, de taxas, das diversas divisões zonais são poucas citações comparado à quantidade de assuntos que o livro aborda sobre o continente Africano, e o mesmo pode se dizer sobre a realidade afro-brasileira, e isso de forma direta, sem contar as diversas citações transversais. Do início ao fim do Volume 3, o livro continua abordando questões africanas e afrodescendentes de formas diretas e transversais, através de textos, fotos, gráficos e gravuras como a questão do Apartheid, migrações, fronteiras, cultura e sistema de atividades econômicas.

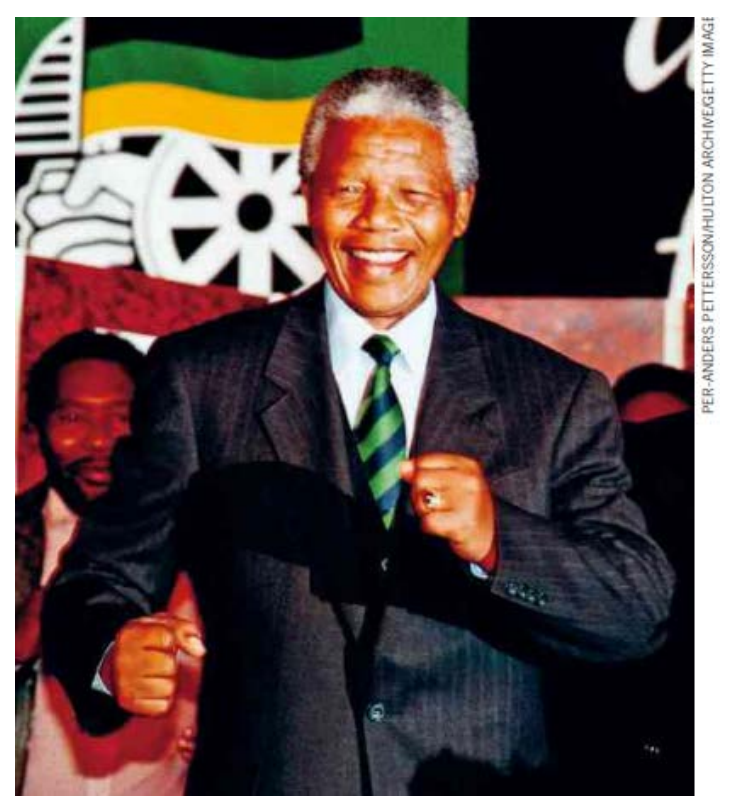

IMAGEM 29: Nelson Mandela, na festa da vitória do CNA, em 2 de maio de 1994, em Johanesburgo. Ele celebrava a vitória na primeira eleição democrática da África do Sul após o fim do apartheid. Página 77 do livro TERRITÓRIO E SOCIEDADE NO MUNDO GLOBALIZADO: ENSINO MÉDIO VOLUME 3 (2016). 


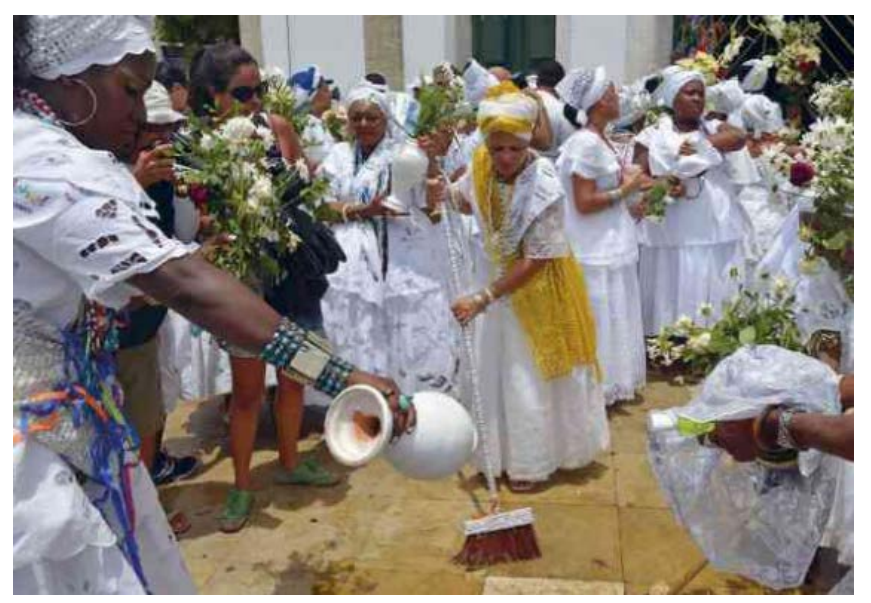

IMAGEM 30: A festa da lavagem do Bonfim, em Salvador (BA), fotografia de 2014. Página 219 do livro TERRITÓRIO E SOCIEDADE NO MUNDO GLOBALIZADO: ENSINO MÉDIO VOLUME 3 (2016).

\section{CONSIDERAÇÕES FINAIS}

O livro “GEOGRAFIA: ENSINO MÉDIO (2007)” será tratado nessa sessão como “Livro 1” e TERRITÓRIO E SOCIEDADE NO MUNDO GLOBALIZADO: ENSINO MÉDIO Volumes 1, 2 e 3 serão tratados somente como “Livro 2".

O Livro 1, é carente de informações, apesar de haver alguns acertos, ele está muito longe de ser o ideal, não há representatividade de um povo que basicamente ajudou a construir grande parte do que a "Geografia do Brasil” estuda. Pela questão da cor dos personagens você pode até ficar confuso, mas no meio dessa confusão só há duas perguntas: há pouquíssima representatividade negra, ou há representatividade negra embranquecida e estereotipada? Independente de sua resposta, o fato é que falta representatividade, e principalmente informações. E isso fica nítido quando analisamos o Livro 2, que apesar de algumas faltas, é quase impecável quando se trata dos assuntos que interessam a esse artigo.

Não com intenção de comparar um livro feito pra alunos e um feito para professores, mas o fato de existir uma área com orientações sobre como ter didática em relação à assuntos de cunho social já faz o Livro 2 ganhar pontos, mas comparando algo que é semelhante entre os dois, como por exemplo a estruturação e a explicação inicial de como o livro vai funcionar com certeza é um bônus necessário. No decorrer do Livro 2, as explicações, as anotações, as informações adicionais, as atividades, as ilustrações, etc fazem com o que o livro seja fácil de digerir mesmo ele tendo uma variedade enorme de assuntos sendo tratados.

O Livro 2 cumpre com o objetivo da meta de não apagar a cultura europeia dos livros didáticos, mas ensinar sobre todas as outras origens igualmente e representa-las de forma digna e verossímil. 
Esse livro tem uma quantidade grande de imagens representando negros, brancos, asiáticos, etc, a ponto de eu precisar racionar quais imagens deveria colocar aqui, não há nenhuma imagem vexatória para as pessoas racializadas. O livro 2 não se atentou somente à uma narrativa generalizada sobre pobreza de africanos e seus descendentes, ele fez uma analise completa sobre a geografia física e humana da África, analisando-a em todos os aspectos, independente se o aspecto é econômico ou climático. O livro também pauta assuntos importantes para a realidade afro-brasileira, não se prende somente às estatísticas sobre violência, mas também fala da importância de ações afirmativas e cotas, fala sobre aspectos culturais e faz críticas fortes ao racismo.

Mesmo o segundo sendo quase impecável aos meus olhos, por quê ele está em análise? Primeiro, para mostrar o quão carente de informações e representatividade o Livro1 é, e segundo, porque os dois livros seguem conceitos geográfico e correntes que talvez não sejam tão benéficas à pauta.

O racismo está entrelaçado na sociedade, a escravidão foi e ainda é um dos frutos do capitalismo e da nova forma de "desenvolvimento" dos Estados, sendo esse sistema endossado e perpetuado pelo Estado em si e pelas elites racistas que pertencem à nossa sociedade. Quando o Livro 1 disse que o território brasileiro "nasceu” com a rixa de portugueses e ingleses e que o espaço indígena não era território pois não era organizado por um “Estado de verdade”, e quando o Livro 2 falhou em explicitar que o quilombo foram terras apropriadas e territorializadas e não cedidas, isso mostrou que o conceito de território não é um conceito que nos cabe. Quando essas falas, que parecem simples, aparecem no meio do texto e mostram que o conceito de poder e de territorialização estão nas mãos do Estado, e como isso seria benéfico para o estudo e ensino de assuntos relacionados à chamada "negritude” se esse é o Estado “político, bem organizado e com poder real” que ainda endossa o preconceito, invadiu terras, matou povos nativos, escravizou negros, tomou terras, tentou destruir símbolos e culturas africanas, impedir afrodescendentes de estudar e ter terras, etc? Existe sim a necessidade de tirar do imaginário popular que o “poder” está somente nas mãos do Estado, e a melhor forma de fazer isso seria nos livros didáticos. O território é o foco pois é a forma de espaço mais ligada ao poder e à política, e não se engane achando que o racismo é somente uma questão

social e não político-econômica.

Em seu livro “Por Uma Geografia do Poder” (1980), Raffestin se posiciona contra a ideia ratzeliana de que o poder está somente no Estado, para ele, o poder está em toda forma de organização. Se o poder está em toda forma de organização, e as relações de poder no espaço são o que formam o território, então é seguro dizer que indivíduos e grupos, mesmo que oprimidos, podem criar território. O território para Raffestin, é o espaço construído à imagem do grupo, delimitado pelo mesmo, 
baseado nas relações de poder que existem ali (sempre lembrando que não precisa ser violento para ser poder), e partir de um certo momento o espaço começa a condicionar os indivíduos também pois as relações e o sentimento de pertencimento influenciam eles. O conceito de território aqui vai encaixar exatamente no que queremos implantar, o espaço de negros e indígenas como espaços válidos, reconhecidos, dotados de poder, organização e, principalmente, identidade.

A definição de Estado é uma definição branca, que exclui sociedades organizadas por indígenas e africanos, e essa definição visa justamente primitivizar essas civilizações para não parecer mau aos olhos de alguns o fato de que os europeus tomaram terras, escravizaram e sacrificaram pessoas racializadas. Não importa o quão democrático o Estado pareça ser, ele ainda é um homem branco, hetero, rico e de idade avançada e defenderá interesses de pessoas que se encaixem no perfil. A explicação de Raffestin explicita todo o processo de territorialização e o conceito de territorialidade, mostrando que o processo do território segue a linha indivíduos $\rightarrow$ grupos $\rightarrow$ Estado, mostrando que só existe um Estado porque existem indivíduos naquele território. Quando saquear e matar não territorializou o espaço como portugueses queriam, a solução foi implementar a ideia de que aquele lugar nem mesmo um território era, e durante a escravidão, a solução também foi não considerar quilombos como território real, quando a escravidão acabou, a resolução do Estado foi negar território aos afrodescendentes e indígenas.

É notório a potencia que o conceito de espaço tem, e a mudança que proponho vem nele, para que o poder real saia das mãos do Estado racista é necessário que o povo em formação reconheça o poder nos indivíduos, sem poder não há território, e sem território não há espaço reconhecível pela elite branca, o Estado reconhece a força dos conceitos do território, a academia racista também, é por isso que forçam conceitos que dão poder ao Estado, que endossa suas crenças.

Como vejo pelos olhos da Geografia, não penso no espaço como a natureza por si só, o que seria trabalho de outras áreas, mas o espaço a partir da interação humana. Pensando assim, sugiro que, assim como Raffestin sugeriu, o espaço seja tratado como uma espécie de "tela em branco" que a partir da interação de grupos ou indivíduos e a partir da perspectiva de análise se torne um conceito como território ou lugar.

Talvez soe como uma grande teoria da conspiração, mas estudando a história e fazendo parte dela, é possível identificar que, até mesmo um conceito usado de uma forma errada passa uma mensagem, e é nos conceitos que sugiro uma mudança, pois se o conceito de território realmente fosse o Norte dos livros, algumas coisas não estariam escritas. Até mesmo o Livro 2, que considero com um dos melhores que eu já li, quase impecável, se esquece do que um território realmente é quando fala dos quilombos (apesar de tratar do conceito de acordo com o proposto durante o livro). 
Sendo a Geografia uma ciência poderosa, podendo ser a cura e o veneno, é importante que conceitos sejam aplicados de forma mais adequada pensando naqueles que o Estado atingiu e continua atingindo até hoje, uma palavra pequena carrega um peso enorme, e usada de forma errada, pode mudar o curso dos acontecimentos, deturpar histórias e diminuir conhecimentos e existências.

\section{REFERÊNCIAS}

ALFLEN, André Aparecido; ZAMBONE, Gisele; RUIZ, João Carlos; MOURA, Leda Maria Corrêa; GARCIA, Márcia Regina \& LOCH, Rosélia Maria Soares. GEOGRAFIA: ENSINO MÉDIO. Segunda edição. Paraná: SEED - PR, 2007.

LUCCI, Elian Alabi; BRANCO, Anselmo Lazaro \& MENDONÇA, Cláudio. TERRITÓRIO e SOCIEDADE NO MUNDO GLOBALIZADO: ENSINO MÉDIO - MANUAL DO

PROFESSOR Volume 1. Terceira Edição. São Paulo: Editora Saraiva, 2016.

LUCCI, Elian Alabi; BRANCO, Anselmo Lazaro \& MENDONÇA, Cláudio. TERRITÓRIO e SOCIEDADE NO MUNDO GLOBALIZADO: ENSINO MÉDIO - MANUAL DO

PROFESSOR Volume 2. Terceira Edição. São Paulo: Editora Saraiva, 2016.

LUCCI, Elian Alabi; BRANCO, Anselmo Lazaro \& MENDONÇA, Cláudio. TERRITÓRIO e SOCIEDADE NO MUNDO GLOBALIZADO: ENSINO MÉDIO - MANUAL DO

PROFESSOR Volume 3. Terceira Edição. São Paulo: Editora Saraiva, 2016.

RAFFESTIN, Claude. Por uma Geografia do poder. São Paulo: Editora Ática, 1993. (p. 147-217) 